\title{
GEENIRUOKA JA HALLINNAN MUUTOS Tapauksena EU:n ja Kanadan välinen laaja ja kattava vapaakauppasopimus CETA
}

\section{Marko Juutinen}

\begin{abstract}
Abstrakti
Artikkeli käsittelee EU:n ja Kanadan välilä lokakuussa 2014 valmistunutta vapaakauppasopimusta, Comprehensive Economic and Trade Agreement (CETA). Tutkimuskohteena on CETA-sopimuksen elintarviketurvallisuutta käsittelevä SPS-osio. Tutkimuskysymyksiä on kaksi. Ensimmäinen kysymys on geeniruuan turvallisuudesta saatavilla olevan tiedon riippumattomuus SPS-hallinnassa. Toinen kysymys on SPS-hallinnan muutos. Tiedon riippumattomuutta tutkin teoreettisesta näkökulmasta tutkimuskirjallisuuden valossa. Hallinnan muutosta tutkin empiirisesti ja teoreettisesti kolmesta näkökulmasta: analysoin SPS-hallintaa koskevaa CETA-sopimuksen osiota a) uuden perustuslaillisuuden, b) demokraattisen vastuunalaisuuden ja c) liberalismin kautta. Euroopan komission mukaan CETA ei vaikuttaisi EU:n mahdollisuuteen kieltää geeniruuan kauppa ja tuotanto jäsenmaissa. Tutkimukseni ei tue tätä väitettä. Näyttää mahdolliselta, että CETA-sopimus johtaa hallinnan muutoksen, jonka ydin on poliittisen päätösvallan korvautuminen asiantuntijavallalla. Tätä voidaan pitää ongelmallisena, koska geeniruuan turvallisuudesta saatavilla oleva tietoa ei voida pitää automaattisesti objektiivisena ja riippumattomana.
\end{abstract}

Avainsanat: CETA, vapaakauppa, elintarviketurvallisuus, SPS, geeniruoka, hallinto, vastuunalaisuus, riippumaton tieto, uusi perustuslaillisuus, liberalismi 


\section{Tausta ja tavoitteet}

EU:n ja Kanadan väliset neuvottelut laajasta ja kattavasta vapaakauppasopimuksesta päättyivät poliittiseen yhteisymmärrykseen 18. lokakuuta 2014. Comprehensive Economic and Trade Agreement (CETA) astuu voimaan aikaisintaan vuonna 2016. Edellytyksenä on Eurooppa-neuvoston ja Euroopan parlamentin hyväksyntä. (EC 18.10.2014; 26.9.2014.) Jos sopimus tulkitaan unionin toimivaltaan kuuluvaksi, hyväksyntää jäsenmaiden parlamenteissa ei tarvita. Toimivaltakysymyksestä päättää Eurooppa-neuvosto komission esityksen pohjalta (EC 16.10.2014).

Vuodesta 2009 neuvotellun sopimuksen tavoitteena on lisätä EU:n ja Kanadan välistä kauppaa, joka komission mukaan voisi kasvaa 23 prosenttia eli 26 miljardin euron arvosta. Komission mukaan kasvu näkyisi sekä bruttokansantuotteen kasvuna että uusina työpaikkoina. BKT:n vuosittainen lisäys olisi noin 12 miljardia euroa. (EC 18.10.2014.) Komission käyttämät luvut perustuvat vuonna 2008 valmistuneeseen EU:n ja Kanadan yhteiseen ennusteeseen, Assessing the Costs and Benefits of a Closer EU-Canada Economic Partnership. Ennusteen taloudellisen osuuden on laatinut Joseph Francois. Sama henkilö vastasi myös EU:n ja Yhdysvaltain välisen vapaakauppasopimuksen taloudellisesta vaikutusarviosta. (EU \& Canada 2008, 28, 50; Francois et al. 2013; Francois 2014.)

Francoisin ja työryhmän hyödyntämää mallia kutsutaan nimellä yleisen tasapainon malli. Sen perusoletus on tuotantovoimien täyskäyttö. Malli ei tunnusta esimerkiksi työttömyyttä, eikä sen vuoksi voi suoraan ennustaa työpaikkojen kasvua (Francois et al. 2013, 71, 96; Kaitila \& Kotilainen 2013, 41). Sen vuoksi komission väite kasvusta ja työpaikosta viittaa sopimuksen tavoitteisiin, mutta sille ei ole kokonaisuudessaan pohjaa komission omassa vaikutusarviossa. Kriitikoiden mukaan alkuoletuksiinsa sidotut yleisen tasapainon mallit tuottavat ylioptimista ja harhaanjohtavaa tietoa liberalisaation vaikutuksista (esim. Stiglitz \& Charlton 2006, 69, 70; Capaldo 2014, 2, 10).

CETA-sopimus ei välttämättä ole kovinkaan merkittävä tekijä kasvun ja työpaikkojen luomisessa. Sen taloudellisia hyötyjä voidaan tutkimuskirjallisuuden valossa pitää kiistanalaisina (Stiglitz \& Charlton 2006; Capaldo 2014). Kriitikoiden mukaan sopimuksen suurimmat vaikutukset ovat toisaalla, sen poliittisissa seurauksissa. Kesällä 2014 kansainvälinen verkosto anoi oikeutta Eurooppalaisen kansalaisaloitteen (ECI) toteuttamiseen. 
Aloitteen tavoite oli keskeyttää EU:n vapaakauppaneuvottelut Kanadan ja Yhdysvaltain ${ }^{1}$ kanssa. Huolena oli, että sopimukset saattaisivat heikentää muun muassa kuluttajansuojaa, ympäristönormeja ja demokraattisen sääntelyn mahdollisuutta tulevaisuudessa. (ECI 2014.) Komissio hylkäsi anomuksen syyskuussa samana vuonna (EC 10.09.2014).

Kansalaisaloitteessa mainitut huolenaiheet heijastelevat kansainvälistä taloushallintaa koskevan monitieteisen tutkijakeskustelun keskeisimpiä tutkimuskysymyksiä. Ne voitaisiin kiteyttää kysymykseen markkinoiden ja demokratian välisestä suhteesta - johon ei ole yhtä oikeata vastausta. Varsin laaja yhteisymmärrys vallitsee kuitenkin siitä, että kysymyksen taustalla on aito ongelma, nimittäin demokraattisen vastuunalaisuuden puute kansainvälisessä taloushallinnassa. Se voidaan määritellä ongelmaksi, koska vastuunalaisuus kuuluu liberaalin demokratian hallinnollisiin periaatteisiin. (Esim. Patomäki \& Teivainen 2003; Grant \& Keohane 2005; Tiihonen 2005; Held \& McGrew 2005; O’Brien \& Williams 2007, ch. 13.)

Monenlaisten toimijoiden käymä keskustelu haarautuu lisäksi useisiin vapaakauppaa koskeviin erityiskysymyksiin. Geeniruoka on yksi niistä. Maailman kauppajärjestö WTO:n vuonna 1995 voimaan astuneen perustamissopimuksen liitesopimuksessa, niin sanotussa SPS-sopimuksessa, määritellään yleiset periaatteet myös geeniruualle. Koska elintarviketeollisuus yleensä ja geeniruoka erikseen vaikuttavat ihmisten terveyteen ja ympäristöön, on kysymys hallinnan periaatteista oleellinen paitsi demokraattisen vastuunalaisuuden, myös terveyden ja ympäristön kannalta. Geeniruokaa koskeva akateeminen keskustelu on käsitellyt esimerkiksi voimassaolevaa sääntelyä ja sen käytäntöjä (Bartsch 2014; Dibden 2011 et al.), tiedon riippumattomuutta (Allesandrini 2010), teollisuuden vaikutusvaltaa (Baines 2014) ja kansalaisten harhaluuloja (Goldstein 2014).

Ajankohtaisesta poliittisesta prosessista eli CETA-sopimuksesta ei vielä juuri ole tuotettu tutkimustietoa ainakaan EU:n instituutioiden ulkopuolella. Tutkimukseni antaa siten oman panoksensa tämän puutteen korjaamiseksi. Rajaan tarkasteluni EU:n ja Kanadan välisen vapaakauppasopimuksen 
SPS-osioon, eli elintarviketurvallisuuden hallintaan ja edelleen geenimuuntelua koskeviin kysymyksiin. Vastaan kahteen tutkimuskysymykseen:

1) Kuinka riippumatonta on geeniruuan turvallisuutta koskeva tieto?

2) Muuttaako CETA:n SPS-osio geeniruokaa koskevaa sääntelyä EU:ssa?

Komission mukaan CETA-sopimus ei vaikuttaisi EU:n valtaan päättää itse geeniruokaa koskevista kysymyksistä. Se ei poistaisi EU:n mahdollisuutta ylläpitää geenimuunneltuja elintarvikkeita kohtaan asetettuja tuonti- ja viljelykieltoja. Se ei heikentäisi EU:n mahdollisuuksia asettaa uusia kaupan esteitä geeniruualle julkisen edun turvaamiseksi:

CETA will not affect EU rules on food safety or the environment. As now, Canadian products will only be able to be imported to and sold in the EU if they fully respect our regulations. For example, CETA does not affect EU restrictions on beef containing growth hormones or GMOs. Nor will CETA restrict either the EU or Canada from passing new laws in areas of public interest such as the environment, and health and safety. (EC 26.9.2014.)

CETA:n sopimusteksti antaa kuitenkin viitteitä siitä, että hallinta tulee muuttumaan: demokraattista sääntelyvaltaa SPS-kysymyksissä on mahdollista purkaa. Tutkimalla SPS-hallinnan muutosta CETA-sopimuksessa voin samalla ottaa kantaa tähän komission väitteeseen.

Artikkelissani on kolme päälukua. Ensimmäisessä luvussa esittelen teoreettisen viitekehyksen. Toisessa luvussa tarkastelen geeniruokaa koskevan tiedon objektiivisuutta tutkimuskirjallisuuden valossa ja teoreettisesta näkökulmasta. Kolmannessa luvussa tutkin hallinnan muutosta CETA-sopimuksen SPS-osiossa. Luku jakaantuu empiiriseen ja teoreettiseen analyysiin. Arvioin muutoksen luonnetta käymällä teoreettista keskustelua kolmen eri näkökulman välillä. Nämä ovat a) uusi perustuslaillisuus (Stephen Gill), b) hallinnon tutkimus (Seppo Tiihonen) ja c) liberalismi (Friedrich Hayek). 


\section{Teoreettinen viitekehys}

Kansainvälisen taloushallinnan tutkimus yhdistää perinteistä demokratiateoriaa, kansainvälisen politiikan tutkimusta, oikeustiedettä, taloustiedettä ja kansainvälisen poliittisen talouden tutkimusta. Teoreettisia näkökulmia on sen vuoksi useita (ks. Palmujoki 2008; Watson 2011). Koska lähtökohtanani on demokratian ja markkinoiden väliseen suhteeseen liittyvä ongelma CETA-sopimuksen geeniruokaa koskevassa SPS-osiossa, olen valinnut kolme toisistaan kaukana olevaa teoreettista näkökulmaa analyysivälineeksi. Uusi perustuslaillisuus näkee vapaakaupan lähtökohtaisesti ongelmallisena, liberalistinen näkökulma puolestaan edustaa vastakkaista näkemystä. Hallinnon näkökulma puolestaan keskittyy demokraattiseen vastuualaisuuteen ja riippumattomaan tietoon. Kyse on tutkimustehtävän perustelemasta ikään kuin neutraalista määritelmästä. Käytännössä myös uusi perustuslaillisuus ja liberalismi ovat näkökulmia hallintoon.

Stephen Gill $(1993,10)$ kutsuu vallitsevan talousjärjestelmän ja talousdiskurssien toimintaa "uudeksi perustuslaillisuudeksi". Kyseessä on Gillin mukaan "sekä eräänlainen oppirakennelma että käytäntöjen ja normien joukko, joka rajoittaa julkisten ja yksityisten taloudellisten organisaatioiden ja instituutioiden demokraattista hallintaa". Uusi perustuslaillisuus rakentaa ja uusintaa sosio-ekonomisia valtasuhteita. Kyse on maailmanlaajuisesta poliittisesta projektista, joka uusintaa ja legitimoi itse itseään, ja joka on saavuttanut hegemonisen aseman ulottamalla kapitalistisen tuotantotavan jokaiseen maailman kolkkaan. Gramscilaista hegemoniateoriaa soveltaen Gill ja Robert Cox kytkevät taloudelliset, poliittiset ja sosiaaliset rakenteet osaksi hegemonista järjestelemää (Gill 1995; 2011; Cox 1993, 62). William Robinsonin ja Jerry Harrisin (2000) mukaan hallitsevana luokkana toimii ylikansallinen kapitalistinen eliitti, joka sitoo ja assimiloi tehokkaasti kansallisia poliittisia eliittejä osaksi itseään.

Gramscilaisesta tai marxilaisesta näkökulmasta vapaakauppasopimukset ovat siten hegemonisen projektin levittämistä ja vahvistamista. Valtiot toimivat siinä hallitsevan luokan välineenä (Robinson \& Harris 2000). Giovanni Arrighin $(1993,182)$ mukaan vapaakauppa on vielä erityisesti Yhdysvaltain imperialismia, jonka avulla muita valtioita sidotaan niiden kansallista autonomiaa rajoittaviin ja purkaviin normeihin. Samalla valtaa 
siirretään demokraattisen kontrollin ulkopuolelle. Tässä yhtälössä Yhdysvallat toimii kansainvälisen kapitalismin imperialistisena koneistona.

Uusi perustuslaillisuus tai kurinalaistava uusliberalismi ehdollistaa ja rajoittaa poliittista päätöksentekoa. Se muokkaa yhteiskunnan rakenteita markkinoiden palvelukseen. Kansalaisen ja valtion rooli määrittyy yhä enemmän markkinoiden näkökulmasta. Gillin käsite "markkinasivilisaatio" kuvastaa tapaa, jolla näitä taloudellisten ja poliittisten eliittien kannalta tarkoituksenmukaisia muutosprosesseja perustellaan ikään kuin kaikille edullisina, hyödyllisinä ja välttämättöminä muutoksina. Käsite nojaa syvälliseen tiedon ja vallan välistä suhdetta koskevaan logiikkaan, foucaultlaiseen valta-analytiikkaan. Gillin tulkinnan mukaan maailmantalouden hallitsevat voimat tuottavat kuvauksia ja määrityksiä todellisuuden luonteesta, ihmisten välisistä vuorovaikutussuhteista sekä yhteiskunnallisesta tarkoituksenmukaisuudesta ilman, että ne irrottautuisivat tai haluaisivat irrottautua omasta asemastaan yhteiskunnassa. Näin diskursiivinen valta näkyy sosioekonomisten ja poliittisten valtasuhteiden uusiutumisena ja vahvistumisena. Kurinalaistava uusliberalismi tulee esitetyksi jonkinlaisena sivilisaatioprosessina. (Gill 1995; 2011; ks. myös Ryner 2006; Jessop \& Sum 2006.)

Taloudellista hallintoa ja tietoa voidaan analysoida myös "ekonomismin" käsitteen avulla. Teivo Teivaisen (2002) teoksessa Enter Economism, Exit Politics ekonomismi viittaa poliittisen harkinnan ja kädenväännön korvaamiseen oikealla "tiedolla". Yhä useammat yhteiskuntaan ja politiikkaan liittyvät kysymykset määritellään kuuluvaksi johonkin erityisasiantuntijuuden piiriin, jolloin poliittinen deliberaatio, eriävät mielipiteet ja demokraattinen päätöksenteko käyvät tarpeettomiksi elleivät suorastaan haitallisiksi. Teivaisen tulkinta ei ole ristiriidassa Gillin tulkinnan kanssa. Ekonomismin käsite jakaa yhteisen kosketuspinnan myös Gilliä valtavirtaisemman hallinnon tutkimuksen kanssa. Esimerkiksi Joseph Stiglitz (2004; 2010) on arvostellut Bretton Woods -instituutioiden, Maailmanpankin ja erityisesti Kansainvälisen valuuttarahaston (IMF) talouspolitiikkaa samansuuntaisilla argumenteilla (vaikka hänen fokuksensa ei olekaan juuri talouden ja demokratian välisessä suhteessa): talouspolitiikan suuntaa ohjasi tietty käsitys "oikeasta talouspolitiikasta". Tämä "oikea" talouspolitiikka, markkinafundamentalismi, selittää paitsi kansainvälisen valuuttarahaston IMF:n epäonnistuneita rakennesopeutusohjelmia 1980-luvulla, myös 
rahoitusmarkkinakriisiä ja nykyistä Euroopan velkakriisiä (ks. myös Patomäki \& Teivainen 2003; Patomäki 2009; Krugman 2012; Quiggin 2014).

Stiglitzin tavoin esimerkiksi Seppo Tiihonen $(2004,25)$ on kritisoinut taloustieteellisesti painottunutta hallintaa Maailmanpankissa. Tiihosen mukaan kansainvälisen taloushallinnan ongelma ainakin Maailmanpankissa liittyisi hallinnan käytäntöihin. Hallinnan legitimiteetti jää heikolle pohjalle, jos päätöksiä tehdään asiantuntijaorganisaatioissa ilman demokraattista vastuunalaisuutta. Toiseksi päätöksentekojärjestelmän kyky käsitellä kaikkea relevanttia informaatiota on kyseenalainen, jos päätöksenteosta vastaavat jonkin yhden erityisalueen asiantuntijat. Ehkä keskeisin ongelma tästä näkökulmasta on, että kansainvälinen taloushallinta vaikuttaa yhteiskunnallisen elämän ydinalueilla, esimerkiksi ympäristönsuojeluun tai elintarviketurvallisuuteen. Sen vuoksi tarvittaisiin poliittisia instituutioita taloudellisen instituutioiden rinnalle (Tiihonen 2004, 26, ks. myös Rodrik 2011). Heikki Patomäen $(2012$, 199) mukaan tarvittaisiin paitsi demokraattisen hallinnan instituutioita ja vastuunalaisuutta, myös alueiden ja valtioiden välisiä tuloeroja ja kauppataseita tasapainottavia keynesiläisiä talouspolitiikan organisaatioita.

Tietoon ja asiantuntijuuteen liittyvät vääristymät kansainvälisessä taloushallinnassa ovat hedelmällistä maastoa myös vallan väärinkäytöksille. Ruth Grantin ja Robert Keohanen (2005) mukaan tulisi kehittää sellaisia instituutioita, jotka pitäisivät yllä ja edistäisivät vastuullista hallintaa samalla ehkäisten vallan väärinkäytökset. Tämän institutionaalisen näkemyksen mukaan demokraattinen hallinta ei ole välttämättä tarpeellista tai todennäköisesti edes mahdollista, mutta vertaisverkostojen ja samoilla hallinnon aloilla toimivien keskinäisiä riippuvuussuhteita olisi mahdollista vahvistaa instituutioita kehittämällä (Grant \& Keohane 2005, 36; Palmujoki 2008, 31.)

Kansainvälinen hallinta, kansainvälinen talous ja vapaakauppa liittyvät siis markkinoiden ja demokratian väliseen suhteeseen. Oikeaa suhdetta ei voida määrittää objektiivisesti. Milton Friedmanin $(1962,15,16)$ ja Friedrich Hayekin (1956 [1944], 69, 70) mukaan markkinat edistävät demokratiaa kaikista parhaiten, koska kuluttaminen on markkinoiden kansalaisuutta. Markkinoilla kansalaisuus on paljon vahvempaa kuin politiikassa, koska vaalit toistetaan päivittäin, ja jokainen dollari tai euro on yksi ääni. 
Äänestyksen perusteella päätetään siitä, kuka saa ja miten paljon. Kuluttajat päättävät myös siitä, kenen yritys menestyy ja kenestä tulee rikas.

Hayekilaisessa liberalismissa vapaus tarkoittaa ulkoisten rajoitteiden puutetta ja ilmenee ensisijaisesti vapautena aktiiviseen toimintaan. Toiminnallisen ulottuvuuden lisäksi vapautta määrittää vastuu. Ilman vastuuta omista teoistaan ei paha saa palkkaansa tai hyvä palkkiotaan. Vastuullisuus mahdollistaa, että hyvien ja muiden arvostamien palvelusten tai hyödykkeiden tuottaja saa niistä palkkion sen mukaan, kuinka paljon hänen työtään arvostetaan. Vastuun positiivinen puoli on siis oikeus nauttia oman työnsä ja menestyksensä hedelmistä. Sen negatiivinen puoli on velvollisuus vastata itse tappioistaan, ja tämä on aivan yhtä tärkeä osa. Ilman jompaakumpaa vääristyy markkinoiden kyky välittää oikeata tietoa, ja ilman vastuuta rakennetaan pohja väärinkäytöksille. (Hayek 2006 [1969], 70, 71.)

\section{Geeniruoka ja tieteellinen tieto SPS-hallinnassa}

SPS-hallinta tarkoittaa elintarviketurvallisuuden hallintaa eli niitä periaatteita ja käytäntöjä, joiden avulla varmistetaan turvallisten ja riskittömien elintarvikkeiden kauppa. Maailman kauppajärjestön SPS-sopimuksessa terveyden suojeluun liittyvä periaate on tieteellisyys. Markkinoille tuotavien elintarvikkeiden, lihan, rehun ja viljan on oltava turvallisia kuluttajalle, ja tämä on todistettava tieteellisesti. Todistamisen tulee tapahtua tieteellisten kriteerien mukaisesti. Elintarvikkeiden kauppaa ei saa rajoittaa enempää kuin on terveyden suojelun kannalta välttämätöntä, eikä sääntelyä saa käyttää välineenä kansainvälisen kaupan rajoittamiseksi. Lisäksi WTO:n jäsenten tulee yhtenäistää elintarviketurvallisuuden sääntelyä ja nojata kansallisessa sääntelyssä kansainvälisesti hyväksyttyihin standardeihin ja suosituksiin. Nämä suositukset koskevat riittävän suojelun tasoa ja riskin määrittelyä kuitenkin siten, että kaupan esteet minimoidaan. (WTO 1994, SPS, art 2, 3, 5.)

Teoreettisesta näkökulmasta SPS-hallinnan yksi olennaisimmista kysymyksistä on, millä perusteella päätöksiä geenimuunneltujen elintarvikkeiden kaupasta tehdään. Stephen Gillin (1995) markkinasivilisaation käsitteessä markkinoita ja markkinoiden hyötyjä koskeva tieto määrittyy hallinnan välineeksi, yhteiskunnallisen ymmärryksen ja legitimaation tuotantotavaksi, 
joka ylläpitää ja uusintaa sosio-ekonomisia valtasuhteita. Tästä näkökulmasta tieto on poliittisesti tarkoituksenmukainen representaatio. Tieto ei ole objektiivista. (Ks. myös Shapiro 1987; de Goede 2006.) Oikean tiedon ongelma SPS-hallinnassa voidaan esittää myös neutraalimmin: olennaista olisi tiedon riippumattomuus ja hallinnan demokraattinen vastuunalaisuus. Tässä tulkitsen Seppo Tiihosen (2006) käsityksiä hyvästä hallinnasta. Hayekilaisesta näkökulmasta demokraattinen vastuunalaisuus ei ole yhtä olennaista. Olennaista kuitenkin on mahdollisuus tehdä ostopäätökset oikean tiedon perusteella, ja ennen kaikkea se, että mikään yksittäinen taloudellinen tai poliittinen intressi ei voi vääristää markkinoita omaksi hyödykseen valheellisen tiedon perusteella.

Kysymys siitä, onko geeniruoka turvallista, ja onko elintarvikemarkkinoiden hallinta parhaiten järjestettävissä nykyisten asiantuntijaorganisaatioiden valtaa kasvattamalla, on siis tärkeä kaikista näistä kolmesta näkökulmasta. CETA-sopimuksessa kaavaillun SPS-hallinnan hyötyjä ei voi perustella yksiselitteisen myönteisesti mistään näistä kolmesta näkökulmasta, eli ne kaikki antavat välineitä CETA-sopimuksen tämän osion kritiikkiin.

Sen sijaan CETA-sopimuksessa esitetty SPS-hallinta näyttäytyy myönteisessä valossa, jos tarkastellaan GMO-tuotteita koskevia bioteknologiateollisuuden käsityksiä, mutta myös suomalaisten viranomaisten laatimia asiaa koskevia selvityksiä. Yhdysvaltalaista bioteknologiateollisuutta edustava Biotechnology Industry Organizationin (BIO) mukaan maailman elintarvikehuolto, ilmastonmuutos ja kestävä ympäristönkäyttö edellyttävät bioteknologista maataloutta - eli muuntogeenisiä viljelykasveja. Ne kestävät paremmin kuivuutta, ne ovat runsassatoisempia ja ne vaativat vähemmän viljelypinta-alaa. (BIO 2013, 13-17.) Samoja perusteluja käytetään Maaja metsätalousministeriön Geenitekniikkastrategiassa ja toimenpideohjelmassa vuosille 2009-2013 sekä Työ- ja elinkeinoministeriön raportissa Bioteknologia 2020 - hyvinvointia suomalaisille. (Ks. myös Goldstein 2014.)

BIO edustaa yli 1100 yritystä ja bioteknologia-alan tutkimuskeskusta. Valta-osa sen jäsenistä on pieniä ja keskisuuria yrityksiä, eivätkä ne rajoitu maatalouteen. Jäsenet edustavat myös terveys-, ympäristö- ja energia-alan yrityksiä. Järjestön mukaan sen aktiivinen toiminta on edistänyt satojen tuhansien työpaikkojen luomista Yhdysvalloissa ja Euroopassa. Ennen kaikkea bioteknologiateollisuus palvelee maailman ihmisiä kehittämällä 
välineitä heidän terveydestään, ravinnostaan ja energiansaannista huolehtimiseen. (BIO 2013, 1.) Geeniruoka on siis vain yksi bioteknologian sovellus. Myös lääketeollisuus kuuluu bioteknologia-alaan. Bioteknologia-alan ja geeniruuan yritysjätti Monsanto on yksi järjestön sadoista jäsenistä (BIO 2014). Monsanto on jäsenenä myös eurooppalaista bioteknologiateollisuutta edustavassa järjestössä EuropaBiossa, jonka mukaan tieteellinen todistusaineisto geeniruuan turvallisuudesta on valtava ja ylivoimainen (EuropaBio 2013; 2014; myös Goldstein 2014, 196-198).

Jotkut tutkijat ovat kuitenkin kyseenalaistaneet nämä tieteelliset todistukset (Allessandrini 2010, 16-18). Jeffrey Smithin (2005, 23, 145-148) teoksessa Petoksen siemenet kirjailija raportoi geeniruuan turvallisuutta koskevien tutkimusten perustuvan puutteelliselle tutkimukselle ennen kaikkea siksi, että Monsanton johdolla bioteknologiateollisuus onnistui löysentämään turvallisuusvaatimuksia ja väljentämään sääntelyä. Smith $(2005,149)$ kirjoittaa: "Monsanto oli siis saanut [...] mitä oli halunnutkin: valtiovallan takuun gm-tuotteiden turvallisuudesta ja vapautuksen säännöksistä, jotka olisivat voineet sotkea sen suunnitelmat markkinoiden nopeasta valtaamisesta ympäri maailmaa."

Kaksi seuraava tapausta osoittavat, että geenimuunneltujen elintarvikkeiden turvallisuudesta tehdyt tieteelliset tutkimukset eivät aina vastaa hyvää tieteellistä käytäntöä tai että tutkimusmentelmät geenimuunneltujen lajikkeiden vaikutuksista eivät yksiselitteisesti osoita tuotteiden turvallisuutta. Ensimmäisessä päähenkilönä on biokemisti Arpad Pusztai joka toimi tutkijana The Rowett Institute -nimisessä ravitsemustieteen tutkimuslaitoksessa. Pusztai teki 1990-luvulla tutkimuksia geenimuunnellulla perunalla. Perunan DNA:han oli yhdistetty lumikellossa luonnostaan esiintyvää ihmisille vaaratonta hyönteismyrkkyä lektiiniä. Tutkimus perustui siihen, että lektiini on vaaraton rotille. Tämän hän oli pystynyt todistamaan syöttämällä suuria määriä ainetta rotille ilman haittavaikutuksia. Perunoissa lektiinin määrä oli satakertaisesti pienempi. Hypoteesi oli, että GMO-peruna ei vaikuttaisi rottiin millään tavalla. GMO-peruna voisi suojautua paremmin hyönteisiä vastaan kuin tavallinen peruna, mutta olisi muuten samanlainen kuin tavallinen. Tutkimus osoitti hypoteesin väääksi. GMO-perunaa syöneillä rotilla negatiivisia vaikutuksia ilmeni kymmenessä päivässä: valkosolujen reaktiivisuus laski ja immuunijärjestelmä heikentyi. 
Joidenkin rottien maksassa, aivoissa ja kiveksissä tapahtui muutoksia. (Smith 2005, 15, 20-21.)

GMO-peruna tuotti siis vaikutuksia, joita pelkästään tavallisella perunalla ja hyönteismyrkyllä erikseen annettuina ei ollut. Ne tuottivat jotakin uutta, ja tämä uusi vaikutus oli terveydelle vaarallinen. Lisäksi GMO-perunan ravintoarvossa tapahtui muutos. Lektiinin lisääminen alensi perunan proteiinipitoisuutta 20 prosenttia, vaikka tätäkään vaikutusta ei geenimuuntelulla olisi pitänyt olla. Sen pitäisi vaikuttaa vain täsmäaseena hyönteisiä vastaan. Tällaisia tutkimuksia geenimuunneltujen tuotteiden turvallisuudesta ei Pusztain mukaan tehdä. (Smith 2005, 21, 22.)

Toinen tapaus on Intiasta ja keskittyy Monsanton puuvillaan, johon on lisätty bt-proteiinia samassa täsmäaseen ominaisuudessa, jossa Pusztai käytti lektiiniä laboratoriotestissään. Tieteelliset testit vakuuttivat sääntelyviranomaiset tuotteen turvallisuudesta, ja vuonna 2002 Monsanto sai luvan bt-puuvillan käyttöön. Testeissä oli tutkittu, onko muunnellun lajikkeen siemenillä haitallisia terveysvaikutuksia. Tulos oli kielteinen. Intiassa siis viljeltiin bt-proteiinia sisältävää puuvillaa samoilla alueilla, joilla laidunsi karjaa. Vuonna 2006 Anthra-niminen järjestö käynnisti omat tutkimuksensa erilaisissa olosuhteissa, koska puuvillan viljelyalueilla lampaiden ja karjan kuolemat olivat yleistyneet. Nyttemmin ovat yleistyneet myös maanviljelijöiden itsemurhat. Monsanton (2014) mukaan yhteyttä asioiden välillä ei ole, ja tutkijat ovat siitä montaa mieltä (vrt. Goldstein 2014, 198; Desmond 2014, 2, 3). Donatella Alessandrinin mukaan tapaus osoittaa, että vaikka siemenet eivät olisi olleet haitallisia, ei se tarkoita, että myös puuvillan lehdet ja jämät karjan ravinnon joukkoon päätyessään eivät olisi haitallisia. (Alessandrini 2010, 16, 17.) Toisaalta Daniel Goldstein (2014, 195 , 198) pitää juuri tapausta yhtenä esimerkkinä poliittisesta taktikoinnista bioteknologisia sovelluksia tuottavia yrityksiä vastaan - koska bt-kritiikille ei ole tieteellisiä perusteita (Bartsch 2014, 54).

Jonkin yrityksen tai teollisuudenalan intressi sääntelyn muuttamisessa ei sinänsä tarkoita vielä mitään väärä.̈. Siitä tulee ongelma vasta siinä vaiheessa, kun sääntelyn muutos ei enää turvaa elintarvikkeiden riskittömyyttä. Elintarviketurvallisuuden tapauksessa tämä ei ole ainoa ongelma, koska geeniruoan politiikkaan liittyy myös kysymys patenttioikeuksista. Patenttimaksut muuttavat maatalouden ja elintarvikemarkkinoiden valtasuhteita. Maataloudessa ne luovat epäsymmetrisiä valtasuhteita maanviljelijöiden ja 
patenttioikeuksien haltijoiden kesken. Elintarvikemarkkinoilla tämä näkyy siinä, että ruuan ja ruokaturvallisuuden hallinta keskittyy: kauppoihin tuleva ruoka ei ole riippuvaista vain maanviljelijöistä vaan myös Monsanton kaltaisista yrityksistä. Sellaisessa hypoteettisessa maailmassa, jossa kaikki maailman ruoka olisi bioteknologiateollisuuden hallitsemaa, levittämää ja tuottamaa, voisi teollisuus periaatteessa päättää siitä, saavatko ihmiset ruokaa ja mitä he syövät. Detlef Bartschin $(2014,56)$ mukaan tämän suuntaiset uhkakuvat ovat esimerkki geeniteknologiaan liittyvistä populaarikulttuurin väärinymmärryksistä ja politisoinnista.

Joseph Baines (2014) mukaan Yhdysvalloissa on nähtävissä elintarvikemarkkinoiden rakennemuutos bioteknologia-alan yritysten hyväksi. Yritysjättien valta koskettaa myös maailman elintarvikemarkkinoita, mutta ennen kaikkea se liittyy ruokaomavaraisuuteen: patenttimaksut ja steriilit lajikkeet heikentävät sitä. Toisin sanoen, kyse on paitsi ruuan riskittömyydestä, myös tiedon omistamisesta ja vallasta hallita ruokaa sekä ruuantuotantoa. Jasanoffin (2006) mukaan bioteknologiateollisuus voikin käyttää tiedollista ja taloudellista asemaansa välineenä vahvistaa hallinnan epädemokraattisia ja imperialistisia rakenteita, minkä vuoksi myös SPS-kysymysten demokraattinen hallinta olisi tärkeää.

\section{SPS-hallinta CETA:ssa}

\subsection{Empiirinen osa}

CETA-sopimuksen SPS-osion tavoitteita on kolme: a) edistää ihmisten, eläinten ja kasvien terveyttä ja samalla helpottaa kaupankäyntiä, b) estää perusteettomien kaupan esteiden syntyminen elintarviketurvallisuuden hallinnasta ja c) edistää Maailman kauppajärjestö WTO:n SPS-sopimuksen toteutumista EU:n ja Kanadan välisessä kaupassa (Art. 2). Osiossa on 15 artiklaa ja 10 liitettä.

EU:ssa elintarvikkeiden riskittömyyttä valvoo Euroopan elintarviketurvallisuusviranomainen, European Food Safety Authority EFSA. Sen mukaan myös geenimuunnellut viljalajikkeet ja hormoniliha ovat turvallisia. Yhdysvaltain vastaavat viranomaiset suhtautuvat samalla tavalla. (Bartsch 2014, 55; Goldstein 2014, 195.) Geenimuunneltujen elintarvikkeiden kauppa on 
kuitenkin EU:ssa ollut käytännössä kiellettyä, koska jäsenmaat eivät ole sidottuja noudattamaan EFSA:n suosituksia (Bartsch 2014, 51, 52). Muuttaako CETA-sopimus tämän tilanteen? Siltä vaikuttaisi. CETA-sopimuksen SPS-osion seitsemännessä artiklassa todetaan (CETA, luku 7, art. 7):

The importing Party shall accept the SPS measures of the exporting Party as equivalent to its own if the exporting Party objectively demonstrates to the importing Party that its measure achieves the importing Party's appropriate level of protection.

Tavoitteena on SPS-hallinnan yhteensovittaminen: Jos jokin tuote on tieteellisesti osoitettu turvalliseksi Kanadassa, ja jos EFSA sen hyväksyy, ei sen kaupalle EU:ssa tulisi asettaa esteitä. Lisäksi seitsemännen luvun artiklassa 4 todetaan, että sopimus kattaa kaikki sellaiset toimet, jotka SPS-kysymyksiin liittyen vaikuttavat suorasti tai epäsuorasti osapuolten väliseen kauppaan (CETA, luku 7, art 4):

This Chapter applies to all SPS measures that may, directly or indirectly, affect trade between the Parties.

CETA-sopimus näyttää muuttavan EU:n nyt voimassaolevia oikeuksia eli riisuvan jäsenvaltioilta oikeuden kieltää EFSA:n hyväksymien geenimuunneltujen elintarvikkeiden maahantuonti ja myynti. Jäsenvaltioiden poliittisin perustein (Bartsch 2014, 55) harjoittama SPS-hallinta korvataan WTO:n edellyttämällä ja CETA-sopimuksen vahvistamalla tieteellisellä hallinnalla. Tieteellinen hallinta perustuu biotekniseen erityisosaamiseen. Huomionarvoista on, että EU ei ole saattanut voimaan WTO:n SPS-sopimuksen mukaista järjestelmää, koska se ei ole hyväksynyt EFSA:n hyväksymien geenimuunneltujen elintarvikkeiden maahantuontia. Näiden päätösten syy on ollut poliittinen, ja ne ovat olleet aiheena kauppariitoihin EU:n ja Yhdysvaltain välillä. Välineellinen syy on ollut institutionaalinen: EU on antanut jäsenmaille mahdollisuuden ylläpitää korkeampaa sääntelytasoa, jos ne ovat niin päättäneet. Samoin EU-tasolla on neuvostossa voitu kieltää komission hyväksyttäväksi esittämät ja EFSA:n suosittelemat GMO-tuotteet. (Ks. Tiberghien 2009; Ansell \& Vogel 2006; Wiener \& Roger 2002.) 
SPS-luvun artiklassa 15 sovitaan yhteisen SPS-kysymyksiä hallinnoivan komitean perustamisesta (Joint Management Committee for Sanitary and Phytosanitary Measures). Sen tehtävänä on valvoa sopimuksen toteutumista, edistää osapuolten välistä yhteistyötä ja vahvistaa molemminpuolista ymmärrystä WTO:n SPS-sopimuksen voimaansaattamisesta. (CETA, luku 7, art 15; luku 30, art X.02.) CETA-sopimuksen 30. luvussa käsitellään hallintoa. Sopimuksella perustetaan uusi poliittista valtaa käyttävä toimielin, jota ei valita vaaleilla. Tämä CETA Joint Committee myös johtaa alakomiteoita, kuten mainittua SPS-komiteaa (CETA, luku 30, art. X.01, (1-5):

1. The Parties hereby establish a CETA Joint Committee comprising representatives of the European Union, on the one hand, and representatives of Canada, on the other. The CETA Joint Committee shall be co-chaired by the Minister for International Trade of Canada and the Member of the European Commission responsible for Trade, or their respective designees.

3. The CETA Joint Committee is responsible for all questions concerning EU-Canada trade and investment and the implementation and application of the CETA. Either Party may refer to the CETA Joint Committee any issue relating to the implementation and interpretation of the CETA, or any other issue concerning EU-Canada trade and investment.

Komitea vastaa sopimuksen toteutumisesta (CETA, luku 30, art. X.03):

1. The CETA Joint Committee shall, for the purpose of attaining the objectives of this Agreement, have the power to take decisions in respect of all matters in the cases provided by this Agreement.

2. The decisions taken shall be binding on the Parties, which shall take the measures necessary to implement the decisions taken. The CETA Joint Committee may also make appropriate recommendations. 
3. The CETA Joint Committee shall make its decisions and recommendations by agreement between the Parties.

Yleensä vapaakauppasopimuksilla ei perusteta uusia yhteisiä toimielimiä. Sen sijaan ongelmatilanteiden varalle sovitaan riitojenratkaisumenettelystä. Riitojenratkaisu kuuluu myös CETA-sopimukseen, mutta siinä on lisäksi uusi poliittinen toimielin. Suhteessa Suomeen ja EU:n jäsenvaltioihin se on ylikansallinen toimielin samalla tavalla kuin Euroopan komissio. EU:n ja Kanadan välisenä instituutiona se on hallitustenvälinen, koska se tekee päätöksensä yhteisymmärryksessä molempien sopimusosapuolten kanssa. CETA-sopimus sitoo SPS-hallinnan entistä vahvemmin WTO:n tieteelliseen kehikkoon, jonka mukaan geenimuunnellut elintarvikkeet ovat turvallisia, jos ne on sellaisiksi osoitettu. Lisäksi sopimus antaa institutionaaliset välineet tämän toteuttamiselle luomalla uuden elimen, joka valvoo sopimuksen toteutumista.

\subsection{Teoreettinen osa}

CETA-sopimuksen SPS-osio tukee uuden perustuslaillisuuden vahvistumista. Se voi poistaa demokraattisen vallan elintarviketurvallisuuteen liittyvissä kysymyksissä kansallisilta parlamenteilta, joille se toistaiseksi on kuulunut. Sopimuksella ei luoda uusia demokraattisia elimiä SPS-hallintaa varten, vaan hallinta sidotaan WTO-sopimuksen mukaisesti asiantuntijaorganisaatioiden tuottamaan tietoon. Tässä mielessä SPS-hallinta täyttää teknokraattisuuden kriteerit, mutta hyväksi hallinnaksi sitä ei voitane nimittää. Kuinka varmistetaan elintarviketurvallisuutta koskevien päätösten vastuunalaisuus ja päätöksenteon riippumattomuus? Tämä on hyvän hallinnan kannalta oleellinen kysymys, johon CETA-sopimuksessa ei anneta vastausta. Sen sijaan tutkimuskirjallisuudessa on esitetty väitteitä siitä, että asiantuntijatieto geenimuunneltujen elintarvikkeiden turvallisuudesta ei olisi riippumatonta, vaan että se päinvastoin olisi riippuvaista bioteknologia-alan suurista yrityksistä, Yhdysvalloissa etenkin Monsantosta. (Esim. Baines 2014; Smith 2005.)

Missä suhteessa CETA-sopimuksen SPS-osio sitten on kuluttajakansalaisuuteen? Jotta kuluttaja voi tehdä valintoja erilaisten tuotteiden välillä, ja jotta päätökset tuottajien ja yritysten menestyksestä voisivat olla täysin 
riippuvaisia kuluttajien preferensseistä, täytyy kuluttajien voida valita. Lisäksi heillä täytyy olla välineet perustaa valintansa oikeaan tietoon. Bioteknologiateollisuuden asiantuntijavalta elintarviketurvallisuutta koskevassa oikean tiedon tuottamisessa asettaa kyseenalaiseksi kansalaisten mahdollisuuden saada oikeaa tietoa. Asiantuntijavalta palautuu foucault'laiseen ongelmaan tiedon ja vallan välisestä suhteesta ja vielä vahvemmin gramscilaiseen viitekehykseen. Sinänsä juuri biotekninen tieto ei liity liberalismin ja marxilaisen yhteiskuntatieteen välisiin kiistoihin, joten juuri tässä tapauksessa eri näkökulmista käsin on mahdollista saavuttaa yhteneviä lopputuloksia. Toisin sanoen myös hayekilaisesta näkökulmasta julkisella vallalla voidaan nähdä SPS-kysymyksissä tasapuolisen tiedon saatavuuden varmistamiseen liittyvä rooli.

Toinen liberalismin näkökulmasta oleellinen kysymys on tuotteiden merkintävaatimukset. GMO-tuotteiden merkitä on kuluttajan valintojen kannalta keskeinen. Kuitenkin yhdysvaltalaiset bioteknologiateollisuuden yritykset ovat esittäneet, että merkintävaatimukset ovat turhia sellaisille tuotteille, joiden riskittömyys on jo osoitettu. Seurauksena olisi vain turhia kaupan esteitä. (Harvey 2014.) Kaliforniassa ja Washingtonissa merkintävaatimuksia ei ole. Vaatimuksista käytiin kiivas poliittinen kamppailu 2010-luvulla. Merkintävaatimusten kannattajat kärsivät tappion. (Bartsch 2014, 51).

Teen näistä huomioista sen johtopäätöksen, että demokraattinen hallinta on itse asiassa tarpeellista myös SPS-kysymyksistä huolimatta siitä, tarkasteleeko sitä jälkigramscilaisesta vai liberalistisesta näkökulmasta. Onkin huomattava, että liberalismi yleensä tai Hayek erityisesti eivät suinkaan pyri puolustamaan sellaista järjestelmää, jossa taloudellinen hyötyminen ei tapahtuisi toisia hyödyttävällä tavalla. Tämä jälkimmäinen on liberalismin perusajatuksia. (Hayek 2006 [1969], 83; Harisalo 2006.)

CETA-sopimuksessa merkintävaatimukset asetetaan kaupan teknisiä esteitä koskevaan osioon. Tämän TBT-osion seitsemännessä artiklassa kirjoitetaan, että merkintävaatimukset eivät saa muodostaa kaupan esteitä. Ainoa poikkeus on, jos merkintävaatimuksen taustalla on hyväksyttävä tavoite, jonka täyttämättä jättäminen olisi riskialtista. Tämä on varsin epämääräinen muotoilu. Jos perusperiaate on, että merkintävaatimukset eivät saisi johtaa kaupan esteiden syntymiseen, voidaan GMO-tuotteiden merkintävaatimuksia pitää turhina. Mahdollisuus niiden asettamiselle silti 
voidaan nähdä säilyvän. Luultavasti lopullinen vastaus riippuu siitä, miten tätä tulkitaan.

In accordance with Article 2 of the TBT Agreement, with respect to technical regulations relating to labelling or marking requirements, the Parties shall ensure they are not prepared, adopted or applied with a view to or with the effect of creating unnecessary obstacles to international trade. For this purpose, such labelling or marking requirements shall not be more trade restrictive than necessary to fulfill a legitimate objective, taking account of the risks that nonfulfillment would create. (CETA, ch. 6, art 7.)

CETA-sopimus näyttäisi viittaavaan SPS-hallinnan muutokseen, jossa kansallinen tai demokraattinen päätöksenteko lakkautetaan. SPS-hallinta voidaan keskittää elintarviketurvallisuudesta vastaaville elimille, joiden välisestä koordinaatiosta vastaisi EU:n ja Kanadan välinen yhteinen SPS-komitea. Viranomaistyöskentely puolestaan pohjautuu WTO:n SPS-sopimuksen riskianalyysiin. Tämän voidaan nähdä tukevan sitä väitettä, että CETA-sopimus edistää uutta perustuslaillisuutta ja murtaa pohjaa poliittisen hallinnan mahdollisuuksilta. Edes hayekilaisesta näkökulmasta tämä ei ole suotuisa kehitys, koska se voi haitata kuluttajan mahdollisuuksia tehdä tietoisia valintoja rapauttaen tällä tavalla vapauden perustuslakia sekä sen erästä perusoikeutta, vastuuta. SPS-hallinnassa vastuullisuus edellyttäisi ainakin kuluttajien mahdollisuutta valita geenimuunnellun ja muuntelemattoman ruuan välillä.

\section{Johtopäätökset}

Komission vakuuttelu siitä, että CETA-sopimus ei tule muuttamaan EU:ssa nyt voimassaolevaa tiukkaa GMO-linjaa, vaikuttaa aineiston perusteella väärältä. Aineistosta käy ilmi, että jos sopimus ratifioidaan, se johtaa SPS-hallinnan keskittymiseen ja bioteknisen tiedon vahvistumiseen SPS-hallinnan periaatteena. Toisaalta tämä tutkimustulos ei ole ehdoton, koska uudessa EU:n ja Kanadan välisessä komiteassa päätökset tehdään yhdessä, ja ne vaativat molempien sopimusosapuolten suostumuksen. Toinen empiirinen 
havainto on, että CETA-sopimuksella luodaan uusia, suomalaisten ja EU:n jäsenmaiden näkökulmasta ylikansallisia hallinnan rakenteita, jotka saavat vastuulleen sopimuksen valvonnan. Jos sopimus ratifioidaan, se todennäköisesti kaventaa vahvasti demokraattisen päätöksenteon mahdollisuutta SPS-hallinnassa. Tällöin EU:n nykyinen poliittista harkintavaltaa korostava käytäntö, jonka mukaan jäsenvaltioilla on mahdollisuus itse päättää geeniruuasta omalla alueellaan, ja toiseksi, jossa geeniruuan markkinoillepääsy on myös unionitasolla alistettu Eurooppa-neuvoston poliittiselle hyväksynnälle, korvautuisi. Se korvautuisi sääntelyviranomaisten harjoittamalla asiantuntijavallalla.

Teoreettisesti nämä tulokset antavat tukea Gillin teesille kurinalaistavasta uusliberalismista, jonka erään tapauksena CETA-sopimuksen SPS-osaa voidaan pitää. Kun tähän yhdistetään asiantuntijatiedon tai bioteknisen tiedon yhteys bioteknologiateollisuuteen, voi CETA-sopimusta kutsua uhkaksi demokratialle. Se ei liioin edistä hyvää hallintaa, koska hallinnan vastuullisuutta ei ole turvattu, ja koska tieteellinen riskianalyysi voidaan kyseenalaistaa. Se ei liioin näyttäisi olevan puhdas esimerkki liberalistisia arvoja toteuttavasta vapaakauppasopimuksesta. Pikemminkin näyttää epätodennäköiseltä, että sopimus vahvistaisi kuluttajien asemaa. Tällä tavalla se ei olisi yhteensopiva vapauden ja vastuun kanssa. Niinpä yleinen tutkimustulos on, että CETA-sopimus on vahvasti poliittinen sopimus, joka representatiivisena diskurssina toimii ekonomistinen ja biotekninen tieto kaupan ja GMO-tuotteiden eduista ja hyödyistä.

Tämän artikkelin tehtävänä oli vastata kahteen kysymykseen:

1) Kuinka riippumatonta on geeniruuan turvallisuutta koskeva tieto?

2) Muuttaako CETA:n SPS-osio geeniruokaa koskevaa sääntelyä EU:ssa?

Tutkimukseni perusteella riippumattoman tiedon saatavuus SPS-hallinnassa näyttää kyseenalaiselta. Arvioni perustuu ensisijaisesti tutkimuskirjallisuuden tarkasteluun. Tarkempi johtopäätös koostuu seuraavista kohdista: a) tutkimuskirjallisuuden mukaan geeniruuan turvallisuudesta vastaavat viranomaiset pitävät geeniruokaa turvallisena tieteellisin perustein, b) osassa tutkimuskirjallisuutta tieteelliset perusteet on kyseenalaistettu, c) osassa 
tutkimuskirjallisuutta tieteellisiä perusteita pidetään hyvinä, d) osassa tutkimuskirjallisuutta teollisuuden valtaa pidetään ongelmana. Näyttäisi siltä, että geeniruuan turvallisuutta ei ole osoitettu riittävän vahvasti. Lopullinen vastaus riippuu riskinsietokyvystä ja toiseksi luottamuksesta sääntelyviranomaisiin. Luottamus puolestaan riippuu hallinnasta ja hallinnan periaatteista. Näin päästään toiseen tutkimuskysymykseen.

Toisen tutkimuskysymyksen empiirinen vastaus on myönteinen. CETA-sopimus näyttää antavan joillekin EU:n ja Kanadan välisille instituutiolle vallan tulkita ja edistää sopimuksen toteutumista. Tämän todennäköisenä seurauksena on geeniruokaa koskevan poliittisen sääntelyn lakkaaminen. Johtopäätökseen vaikuttavat CETA-sopimukseen mahdollisesti asetettavat varaukset ja viime kädessä Euroopan parlamentin jäsenten valveutuneisuus.

Teoreettinen vastaus samaan kysymykseen on, että CETA-sopimus näyttäisi a) edistävän uutta perustuslaillisuutta sekä heikentävän b) demokraattista vastuunalaisuutta kansainvälisessä taloushallinnassa ja c) kuluttajan valinnan vapautta. Johtopäätöksistä viimeinen on heikoin. Se riippuu merkintävaatimuksia koskevasta hallinnasta, josta tämän artikkelin perusteella ei voida vetää vahvoja johtopäätöksiä. ${ }^{2}$

\section{Viitteet}

I) CETA-sopimus on yksi monesta nyt neuvoteltavasta vapaakauppasopimuksesta. Julkisuudessa enemmän on saanut huomiota EU:n ja Yhdysvaltain välinen sopimus transatlanttisesta kauppa- ja investointikumppanuudesta (TTIP). Lisäksi 23 maata neuvottelevat laajasta palvelukauppaa koskevasta sopimuksesta (TISA); Yhdysvallat ja 11 Aasian ja Tyynenmeren valtiota neuvottelevat myös tahollaan laajasta TPP-sopimuksesta. Bruttokansantuoteessa mitattuna vapaakauppaneuvotteluja käyvät valtiot vastaavat yli 60 prosentista maailman BKT:ta. Tämä korostaa tutkimustiedon tarvetta. CETA ja SPS-hallinnan muutos eivät ole yksittäistapauksia. (Ks. Juutinen 2014.)

2) Olen kiitollinen anonyymiltä refereeltä ja Poliittinen talous -lehden päätoimittaja, dosentti Teppo Eskeliseltä saamistani korkeatasoisista parannusehdotuksista ja täsmennyksistä. 


\section{Lähteet}

Alessandrini, Donatella. 2010. GMOs and the Crisis of Objectivity: Nature, Science and the Challenge of Uncertainty. Social \& Legal Studies, 19:1, 3-23.

Ansell, Christopher \& Vogel, David. 2006. What's the Beef? The Contested Governance of European Food Safety. London: MIT Press.

Arrighi, Giovanni. 1993. The Three Hegemonies of Historical Capitalism. Teoksessa Gill, Stephen (toim.), Gramsci, Historical Materialism and International Relations. Cambridge: Cambridge University Press, 128-148.

Baines, Joseph. 2014. Food Price Inflation as Redistribution: Towards a New Analysis of Corporate Power in the World Food System. New Political Economy, 19:1, 79-112.

Bartsch, Detlef. 2014. GMO regulatory challenges and science: a European perspective. Journal of Consumer Protection and Food Safety, 9:1, 51-58.

BIO 2014. [The Biotechnology Industry Organization.] BIO Members \& Web Site Links. Saatavilla http://www.bio.org/articles/bio-members-web-site-links

BIO 2013. [The Biotechnology Industry Organization.] Transatlantic Trade and Investment Partnership (TTIP). Saatavilla http://www.bio.org/sites/default/ files/BIO\%20TTIP\%20submission\%20May\%202013\%20final\%205\%20 10\%2013.pdf

Capaldo, Jeronim. 2014. The Transatlantic Trade and Investment Partnership: European Disintegration, Unemployment and Instability. Global Development and Environmental Institute. Working Paper No. 14-03.

CETA. Comprehensive Economic and Trade Agreement. Saatavilla http://trade. ec.europa.eu/doclib/docs/2014/september/tradoc_152806.pdf

Cox, Robert W. 1993. Gramsci, Hegemony and International Relations: an Essay in Method. Teoksessa Gill, Stephen (toim.), Gramsci, Historical Materialism and International Relations. Cambridge: Cambridge University Press, 49-66.

De Goede, Marieke. 2006. Introduction: International Political Economy and the Promises of Poststructuralism. Teoksessa De Goede, Marieke (toim.), 
International Political Economy and Poststructural Politics. New York: Palgrave Macmillan.

Desmond, Elaine. 2014. "The legitimation of risk and Bt cotton: a case study of Bantala village in Warangal, Andhra Pradesh, India”. Journal of Risk Research. doi: 10.1080/13669877.2014.961516

Dibden, Jacqui \& Higgin, Vaughan \& Cocklin, Chris. 2011. Harmonising the Governance of Farming Risks: agricultural biosecurity and biotechnology in Australia. Australian Geographer, 42:2, 105-122.

EC. 18.10.2014. EU and Canada conclude negotiations on trade deal. Press release. Saatavilla http://europa.eu/rapid/press-release_IP-13-972_en.htm

EC. 16.10.2014. C(2014) 7557final. Euroopan komission vastaus toimivaltaa koskevaan kyselyyn. Saatavilla http://ec.europa.eu/dgs/secretariat_general/ relations/relations_other/npo/docs/slovenia/own_initiative/oi_role_of_national_ parliaments_in_free_trade_agreements/oi_role_of_national_parliaments_in_ free_trade_agreements_assembly_reply_en.pdf

EC. 26.9.2014. Questions and Answers. When Will CETA Become Operational? Saatavilla http://ec.europa.eu/trade/policy/in-focus/ceta/questions-andanswers/

EC. 10.09.2014. C(2014) 6501 final. Your request for registration of a proposed citizens' initiative entitled "STOP TTIP". Saatavilla http://ec.europa.eu/ citizens-initiative/public/documents/2552

ECI. 2014. Self-organized European Citizens Initiative. Saatavilla http://ttip2014. eu/eci.html

EU \& Canada. 2008. Assessing the Costs and Benefits of a Closer EU-Canada Economic Partnership. A Joint Study by the European Commission and the Government of Canada. Saatavilla http://trade.ec.europa.eu/doclib/docs/2008/ october/tradoc_141032.pdf

EuropaBio. 2014. Members. Saatavilla http://www.europabio.org/members

EuropaBio. 2013. Rethinking GMOs, biotech industry encourages Europeans to engage. Saatavilla http://www.europabio.org/press/press-release-rethinkinggmos-biotech-industry-encourages-europeans-engage 
Francois, J. \& Manchin, M. \& Norberg, H. \& Pindyak, O. \& Tomberger, P. 2013. Reducing Transatlantic Barriers to Trade and Investment: An Economic Assessment. Centre for Economic Policy Research, London, commissioned for European Commission. Saatavilla http://trade.ec.europa.eu/doclib/docs/2013/ march/tradoc_150737.pdf

Francois, Joseph. 2014. Kotisivut. Saatavilla http://www.i4ide.org/ people/ francois/

Friedman, Milton. 1962. Capitalism and Freedom. Chicago: University of Chicago Press.

Gill, Stephen. 2011. Valta ja vastarinta undessa maailmanjärjestyksessä. Helsinki: Gaudeamus.

Gill, Stephen. 1995. Globalisation, Market Civilisation, and Disciplinary Neoliberalism. Millennium - Journal of International Studies, 24:3, 399-423.

Gill, Stephen. 1993. Gramsci and global politics: towards a post-hegemonic research agenda. Teoksessa Gill, Stephen (toim.), Gramsci, Historical Materialism and International Relations. Cambridge: Cambridge University Press, 1-18.

Goldstein, Daniel A. 2014. Tempest in a Tea Pot: How did the Public Conversation on Genetically Modified Crops Drift so far from the Facts? Journal of Medical Toxicology, 10:2, 194-201.

Grant, Ruth \& Keohane, Robert O. 2005. Accountability and Abuses of Power in World Politics. American Political Science Review, 99:1, 29-43.

Harisalo, Risto. 2006. Liberaali uudesta liberalismista. Hallinnon tutkimus 1/2006, 47-58.

Harvey, Fiona. 5.9.2014. "EU under pressure to allow GM food import from US and Canada". The Guardian.

Hayek, Friedrich A. 2006 [1969]. The Constitution of Liberty. London: Routledge.

Hayek, Friedrich A. 1956 [1944]. The Road to Serfdom. Chicago: The University of Chicago Press. 
Held, David \& McGrew, Anthony. 2005. Globalisaatio. Puolesta ja vastaan. Tampere: Vastapaino.

Jasanoff, Sheila. 2006. Biotechnology and Empire: The Global Power of Seeds and Science. OSIRIS 21: 273-292.

Jessop, Bob \& Sum, Ngai-Ling. 2006. Towards a Cultural International Political Economy: Poststructuralism and the Italian School. Teoksessa De Goede, Marieke (toim.), International Political Economy and Poststructural Politics. New York: Palgrave Macmillan.

Juutinen, Marko. 2014. Euroopan unionin ja Yhdysvaltain välinen vapaakauppasopimus. Teoksessa Taussi, Thomas \& Juutinen, Marko \& Puisto, Sakari \& Nikolenko, Anton, Kauppa se on, joka kannattaa. Helsinki: Liberasäätiö.

Kaitila, Ville \& Kotilainen, Markku (2013): EU:n ja Yhdysvaltojen mahdollisen kauppa- ja investointikumppanuussopimuksen vaikutuksia suomalaiselle elinkeinoelämälle ja yhteiskunnalle. ETLA Raportit No 8.

Krugman, Paul. 2012. Lopettakaa tämä lama nyt! Helsinki: HS -kirjat.

Maa- ja metsätalousministeriö. 2009. Geenitekniikkastrategia ja toimenpideohjelma vuosille 2009-2013. Helsinki: MMM. Saatavilla http:// www.mmm.fi/attachments/mmm/julkaisut/tyoryhmamuistiot/5GlnksTpm/ trm2009_6.pdf

Monsanto. 2014. Is Bt or GMO Cotton the Reason for Indian Farmer Suicides. Saatavilla http://www.monsanto.com/newsviews/pages/india-farmer-suicides. aspx

Palmujoki, Eero. 2006. Kansainvälisten suhteiden normien rajat. Kosmopolis 38:2, 30-44.

Patomäki, Heikki \& Teivainen, Teivo. 2003. Globaali demokratia. Helsinki: Gaudeamus.

Patomäki, Heikki. 2009. Neoliberalism and the Global Financial Crisis. New Political Science, 31:4, 431-442.

Patomäki, Heikki. 2012. Eurokriisin anatomia. Helsinki: Into. 
Quiggin, John. 2014. Zombitalous. Tampere: Vastapaino.

Robinson, William I. \& Harris, Jerry. 2000. Towards A Global Ruling Class? Globalization and the Transnational Capitalist Class. Science \& Society 64:1, 11-54.

Rodrik, Dani. 2011. The Globalization Paradox: Why Global Markets, States, and Democracy Can't Coexist. Oxford: Oxford University Press.

Ryner, Magnus. 2006. International Political Economy: Beyond the Poststructuralist/Historical Materialist Dichotomy. Teoksessa de Goede, Marieke (toim.), International Political Economy and Poststructural Politics. New York: Palgrave.

Shapiro, Michael J. 1981. Language and Political Understanding. The Politics of Discursive Practices. London: Yale University Press.

Smith, Jeffrey M. 2005. Petoksen siemenet. Voiko kuluttaja luottaa geeniruokaan? Helsinki: Like.

Stiglitz, Joseph \& Charlton, Andrew. 2006. Fair Trade for All: How Trade Can Promote Development. Oxford: Oxford University Press.

Stiglitz, Joseph. 2004. Globalisaation sivutuotteet. Jyväskylä: Like.

Stiglitz, Joseph. 2010. Freefall. Free Markets and the Sinking of the Global Economy. London: Allen Lane.

Teivainen, Teivo. 2002. Enter Economism, Exit Politics: Experts, economic policy and the damage to democracy. London: Zed Books.

Tiberghien, Yves. 2009. Competitive Governance and the Quest for Legitimacy in the EU: the Battle over the Regulation of GMOs since the mid-1990s. Journal of European Integration, 31:3, 389-407.

Työ- ja elinkeinoministeriö: Bioteknologia 2020 - hyvinvointia suomalaisille. Linjaukset bioinnovaatioiden hyödyntämiseksi. Saatavilla https:/www.tem.fi/ files/24697/bioteknologia_final_0909.pdf

Watson, Matthew. 2011. The Historical Roots of Theoretical Traditions in Global Political Economy. Teoksessa Ravenhill, John (toim.), Global Political Economy. Oxford: Oxford University Press. 
JUUTINEN

Politttinen talous 2(2014):1, 9-33

Wiener, Jonathan B. \& Rogers, Michael D. 2002. Comparing precaution in the United States and Europe. Journal of Risk Research 5:4, 317-349.

WTO. 1994. SPS-Agreement. Saatavilla http://www.wto.org/english/docs_e/ legal_e/15-sps.pdf 